\title{
What are the audiometric frequencies affected are the responsible for the hearing complaint in the hearing loss for ototoxicity after the oncological treatment?
}

\section{Quais as frequências audiométricas acometidas são responsáveis pela queixa auditiva nas disacusias por ototoxicidade após o tratamento oncológico?}

\author{
Patricia Helena Pecora Liberman', M. Valeria Schmidt Goffi-Gomez², Christiane Schultz', Luiz Fernando Lopes ${ }^{3}$. \\ 1) Master in Sciences. Speech Therapy. \\ 2) $\mathrm{PhD}$ in Communication Disorder Sciences. Speech Therapist. \\ 3) $\mathrm{PhD}$ in Medicine. Pediatric Oncology. \\ Institution: Hospital AC Camargo. \\ Sao Paulo / SP - Brazil. \\ Mailing address: Patricia Helena Pecora Liberman - 211 Antonio Prudente, st - Sao Paulo/SP - Brazil - Telephone: (+55 11) 2189-5123 - E-mail. phpliberman@ gmail.com \\ Article received in 2011 May $10^{\text {th }}$. Article approved in 2011 August $21^{\text {st }}$.
}

\section{SUMMARY}

Introduction: The neurosensory bilateral simetric hearing loss resulting of the oncological treatment is underestimated, because the patients has the hearing detection preserved, reporting complaints in determined situation, or the not comprehension of part of the message.

Objective: Investigate which are the audiometric frequencies affected are the responsible by the presence of hearing complaints.

Method: Prospective study evaluating 200 patients with cancer in the childhood out of the oncological treatment in at least 8 years, with average age to the diagnosis of 6,21 years $(4,71)$. Was applied anamnesis to investigate the presence of hearing complaints and performed a tonal threshold audiometry. To check the association between the complaint and the hearing loss, was applied the Exact test of Fisher, with one error $a=5 \%$, the patients were split into: normal hearing, hearing loss in $8 \mathrm{kHz}$, loss in $6-8 \mathrm{kHz}$, loss in $4-8 \mathrm{kHz}$, loss in $2-8 \mathrm{kHz}$ and loss in $\leq 1-8 \mathrm{kHz}$.

Results: We found 125 patients with hearing loss, 10 presented hearing complaints. Between the patients with hearing loss, 16 presented loss only at $8 \mathrm{kHz}$, and 1 with complaint; 22 with loss in $6-8 \mathrm{kHz}$, being 3 with complaint; 16 with loss in $4-8 \mathrm{kHz}$, from them 10 with complaint; 15 with loss $2-8 \mathrm{kHz}$, being 14 with complaint and 6 with loss in $\leq 1-8 \mathrm{kHz}$ all with complaints. There were a significant relationship between the loss and hearing complaint $(\mathrm{p}<0,001)$, when the frequency of $4 \mathrm{kHz}$ was involved.

Conclusion: The bigger the number of affected frequencies the bigger the occurrence of hearing complaint, most of all when the speech frequencies are involved, and the involvement of $4 \mathrm{kHz}$ already determines the appearing of the complaints. Keywords: bilateral hearing loss, neurosensory hearing loss, oncology, health impacts.

\section{RESUMO}

Introdução: A perda auditiva neurossensorial bilateral simétrica resultante do tratamento oncológico é subestimada, pois os pacientes têm a detecção auditiva preservada, relatando queixa em determinadas situações, ou a não compreensão de parte da mensagem.

Objetivo: Investigar quais as frequências audiométricas acometidas são responsáveis pela presença de queixa auditiva. Método: Estudo prospectivo avaliando 200 pacientes com câncer na infância fora de tratamento oncológico há no mínimo 8 anos, com idade média ao diagnóstico de 6,21 anos $(4,71)$. Foi aplicada anamnese para investigar a presença de queixa auditiva e realizada audiometria tonal limiar. Para verificar a associação entre queixa e perda auditiva, foi empregado o teste exato de Fisher, com um erro a=5\%. Os pacientes foram divididos em: audição normal, perda auditiva em $8 \mathrm{kHz}$, perda em $6-8 \mathrm{kHz}$, perda em $4-8 \mathrm{kHz}$, perda em 2$8 \mathrm{kHz}$ e perda em $\leq 1-8 \mathrm{kHz}$.

Resultados: Encontramos 125 pacientes com audição normal, 10 apresentaram queixa auditiva. Entre os pacientes com perda auditiva, 16 apresentaram perda somente em $8 \mathrm{kHz}$, e 1 com queixa; 22 com perda em $6-8 \mathrm{kHz}$, sendo 3 com queixa; $16 \mathrm{com}$ perda em $4-8 \mathrm{kHz}$, destes 10 com queixa; $15 \mathrm{com}$ perda $2-8 \mathrm{kHz}$, sendo 14 com queixa e 6 com perda em $\leq 1-8 \mathrm{kHz}$ todos com queixa. Houve relação estatisticamente significante entre perda e queixa auditiva $(\mathrm{p}<0.001)$, quando a frequência de $4 \mathrm{kHz}$ foi envolvida.

Conclusão: Quanto maior o número de frequências acometidas maior a ocorrência de queixa auditiva, sobretudo quando as frequências da fala estão envolvidas, sendo que o acometimento de $4 \mathrm{kHz}$ já determina o aparecimento das queixas.

Palavras-chave: perda auditiva bilateral, perda auditiva neurossensorial, oncologia, impactos na saúde. 


\section{INTRODUCTION}

The Pediatric Department of the Treatment and Research of A C Camargo Hospital, in Sao Paulo, is the oldest in the country and for this reason, we can find patients who were treated in 1953and, currently are off treatment. In order to evaluate the possible sequelae and late effects that would interfere in the quality of life of these subjects, we created a multidisciplinary group GEPETTO (Group of Pediatric Studies about Late Effects of Oncological treatment) which evaluates the patients out of the oncological treatment, in at least for 8 years. Some studies of this group were published and described cardiac sequelae (1), frequency of sequelae by studied diseases 2) and the dentofacial sequelae (3).

One of the possible sequelae of oncologic treatment is the ototoxicity which leads to a bilateral neurosensory hearing loss, damaging especially the high frequencies and may also affect the low frequencies $(4,5,6,7)$.

Hearing loss means losing an important way of contact with the world and with our fellows. Although there are different levels of hearing losses, any blocking in the sound conduction to the hearing nervous system means losing the contents of the message. Such loss is greater in the children for being under development, it may interfere in the language acquisition.

The hearing disorder induced by the use of ototoxics is most of the times underestimated. Despite of presenting hearing loss, the patients only report complaint in determined situations, such as in noisy environment, or refer losing or not comprehend only part of the message, which leads the family for not believing the presence of hearing loss. The loss of the acoustic information diminishes the probability to understand the speech, as the impairment of the high frequencies turns difficult the consonants perception (8).

This associated to the treatment of global neoplasms can contribute to the isolation of the patients with cancer (9).

The objective of this work is to investigate which are the audiometric frequencies affected that are responsible for the hearing complaint in patients treated of cancer in childhood.

\section{METHOD}

In the period of 2000 to 2004 , it was evaluated 200 patients that had cancer in childhood, treated between the periods of 1961-1996, and who was out of oncologic treatment, at least for 08 years. From these 104 (52\%) was of masculine gender and 96 (48\%) of feminine gender. The average age to the diagnosis was of $6,21 \pm 4,71$ years (average \pm DP) (variation: $0-18,6$ ) and at the evaluation it was $21,7 \pm 6,8$ years (variation: $8-56$ ). From these, 51 patients performed treatments that did not included radiotherapy in the head and neck region neither chemotherapy using cisplatin (CDDP), 64 patients were submitted to chemotherapy with CDDP and did not performed radiotherapy in the region of head and neck, 75 patients were submitted to radiotherapeutic treatment in head and neck region without chemotherapy regimen with cisplatin and 10 patients were submitted to radiotherapy (Rxt) in head and neck region as well as chemotherapy with cisplatin.

This study was approved and reviewed by the Ethics and Research Committee (CEP) protocol number 549/03 of AC Camargo Hospital. The eligible patients or their responsible were consulted about the possibility to participate signing a term of consent.

The patients were submitted to an anamnesis at ambulatory of Pediatrics as to investigate the presence of hearing complaint and referred to hearing evaluation at Audiology service, regardless of existence or not of hearing complaint. The questionnaire involved hearing and otologic complaints and it was considered as presence of hearing complaint the positive answer to the question: Do you think that you hear well, as well as more than one question related to the hearing acuity and ringing. The meatoscopy was performed before the examination and if the patient presented cerumen or any suspicion and/ or obstruction which would prevent the test performing, he was referred to otorhinolaryngologist before evaluation.

The audiometric threshold tone was performed with Madsen Orbiter 922 audiometer and TDH39 headset. The hearing lost was considered when the thresholds exceeded 20dB HL in any frequency between 0,25 and 8kHZ (Schultz et al.) (10).

In order to check association between the variables hearing complaint and hearing loss, it was used Fisher's exact test. For the entire statistical test, it was established an error $\mathrm{a}=5 \%$, i.e., the results were considered statistically significant when $\mathrm{p}<0,05$.

The patients were grouped according to the tone audiometric result and presence or not of hearing complaint. It was divided in patients with normal hearing, hearing loss in $8 \mathrm{kHz}$, hearing loss $6-8 \mathrm{kHz}$, hearing loss $4-8 \mathrm{kHz}$, hearing loss $2-8 \mathrm{kHz}$ and hearing loss $\leq 1-8 \mathrm{kHz}$. 


\section{RESULTS}

The hearing loss was found in both ears. In whole group that was submitted to treatment of risk for hearing, according the Graphic 1 shows.

The hearing complaint was present in 44 patients (22\%) of the sample being 34 patients with complaint presented hearing loss. We observed a statistically significant relation between the presence of hearing loss and hearing complaint (Table 1). From patients with complaint and without hearing loss, fours was of the group without treatment risk, four was of the group with treatment with cisplatin, and two were treated only with radiotherapy.

The hearing losses were separated by audiometric frequency, in order to observe in which frequency loss has significant statistically relation with complaint (Table 2 ).

We could observe that the greater the number of frequencies affected by hearing loss, the higher is the onset of hearing complaint showing a statistically significant relation between hearing loss from of $4 \mathrm{kHz}$ and hearing complaint $(\mathrm{p}=0.001)$ (Tables 3 to 7$)$.

\section{DisCUSSION}

The hearing loss induced by the use of ototoxics has been studied, especially in oncologic treatment $(4,5,6,7,11,12)$. Currently the increase in survival rates and with the increasing concern with quality of life of the patients, it is important not only the hearing monitoring, but, especially the hearing rehabilitation and comprehension of the real hearing necessities of each individual. The loss characteristic is described as bilateral, descending and symmetrical $(7,11)$. In fact, the descending hearing implies difficulties of perception of the acute phonemes in speech (8), placing these patients in risk to the communication difficulties, especially in noisy environments.

Although we have found 10 patients (5\%) with normal hearing with presence of complaint, we remember that the ring was considered as complaint and also may be present in individuals with normal hearing $(13,14)$. In fact, Teixeira et al.(15) also found in his population 50 elder individuals, 3 elders (6\%) with normal hearing with complaint.

In our study, we observe that the most of the patients with hearing loss also may have hearing complaint, and that the greater the more frequencies are affected, the greater is the occurrence of hearing complaint. АмоRim et al.

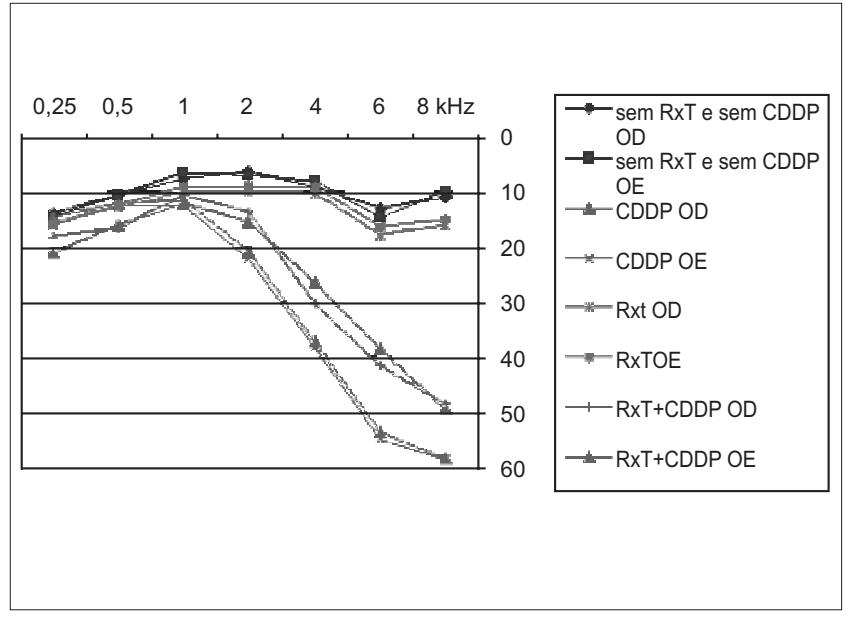

Graphic 1. Configuration of audiometric mean thresholds according to the type of treatment.

Table I. Distribution of the patients with or without hearing loss in relation of hearing complaint.

\begin{tabular}{lcccc}
\hline & $\begin{array}{c}\text { with } \\
\text { compliant } \\
\mathrm{n}(\%)\end{array}$ & $\begin{array}{c}\text { without } \\
\text { compliant } \\
\mathrm{n}(\%)\end{array}$ & $\begin{array}{c}\text { total } \\
\mathrm{n}(\%)\end{array}$ & $\mathrm{P}$ \\
\hline With loss & $34(17 \%)$ & $41(21 \%)$ & $75(38 \%)$ & 0.0001 \\
Without loss & $10(5 \%)$ & $115(57 \%)$ & $125(62 \%)$ & \\
\hline Total & $44(22 \%)$ & $125(78 \%)$ & $200(100 \%)$ & \\
\hline
\end{tabular}

Table 2. Distribution of the patients according to the audiological evaluation resultand presence of hearing complaint.

\begin{tabular}{lccc}
\hline $\begin{array}{l}\text { Evaluation result } \\
\text { audiological }\end{array}$ & $\begin{array}{c}\text { with } \\
\text { complaint }\end{array}$ & $\begin{array}{c}\text { without } \\
\text { complaint }\end{array}$ & total \\
\hline Normal hearing & 10 & 115 & 125 \\
Hearing loss in $8 \mathrm{kHz}$ & 1 & 15 & 16 \\
Hearing loss in $6-8 \mathrm{kHz}$ & 3 & 19 & 22 \\
Hearing loss in $4-8 \mathrm{kHz}$ & 10 & 6 & 16 \\
Hearingloss in $2-8 \mathrm{kHz}$ & 14 & 1 & 15 \\
Hearing loss in $\leq 1-8 \mathrm{kHz}$ & 6 & 0 & 6 \\
\hline Total & 44 & 156 & 200 \\
\hline
\end{tabular}

Table 3. Statistics analysis of distribution of patients with hearing loss in $8 \mathrm{kHz}$ only and without hearing loss related to the hearing complaint.

\begin{tabular}{|c|c|c|c|c|}
\hline & $\begin{array}{c}\text { with } \\
\text { compliant } \\
\mathrm{n}(\%)\end{array}$ & $\begin{array}{l}\text { without } \\
\text { compliant } \\
\mathrm{n}(\%)\end{array}$ & $\begin{array}{l}\text { total } \\
n(\%)\end{array}$ & $\mathrm{p}$ \\
\hline $\begin{array}{l}\text { With loss } \\
\text { in } 8 \mathrm{kHz} \\
\text { Without loss }\end{array}$ & $\begin{array}{c}\text { I (1\%) } \\
10(7 \%)\end{array}$ & $\begin{array}{l}|5(1 \mid \%)| \\
\mid 15(82 \%)\end{array}$ & $\begin{array}{c}6(11 \%) \\
125(89 \%)\end{array}$ & 1.0 \\
\hline Total & ।I (8\%) & 130 (92\%) & 141 (100\%) & \\
\hline
\end{tabular}


Table 4. Statistics analysis of distribution of patients with hearing loss in $6-8 \mathrm{kHz}$ and without hearing loss related to hearing complaint.

\begin{tabular}{lcccc}
\hline & $\begin{array}{c}\text { with } \\
\text { compliant } \\
\mathrm{n}(\%)\end{array}$ & $\begin{array}{c}\text { without } \\
\text { compliant } \\
\mathrm{n}(\%)\end{array}$ & $\begin{array}{c}\text { total } \\
\mathrm{n}(\%)\end{array}$ & $\mathrm{P}$ \\
\hline With loss & $3(2 \%)$ & $19(13 \%)$ & $22(15 \%)$ & 0.4 \\
in 6ke 8kHz & $3(2 \%)$ & $115(78 \%)$ & $125(85 \%)$ & \\
Withoutloss & $10(7 \%)$ & $134(91 \%)$ & $147(100 \%)$ & \\
\hline Total & $13(9 \%)$ & 134 & \\
\hline
\end{tabular}

Table 5. Statistics analysis of distribution of patients with hearing loss in only $4-8 \mathrm{kHz}$ and withouthearing loss related to hearing complaint.

\begin{tabular}{cccc}
\hline $\begin{array}{c}\text { with } \\
\text { compliant } \\
n(\%)\end{array}$ & $\begin{array}{c}\text { without } \\
\text { compliant } \\
n(\%)\end{array}$ & total & P(\%) \\
\hline
\end{tabular}

With loss

between

$\begin{array}{lllll}4 \mathrm{ke} 8 \mathrm{kHz} & 10(7 \%) & 6(4 \%) & 16(1 \mathrm{l} \%) & <0.000 \mathrm{I}\end{array}$

Withoutloss $\quad 10(7 \%) \quad 115(82 \%) \quad 125(89 \%)$

Total $20(14 \%) \quad 121(86 \%) \quad 141(100 \%)$

Table 6. Statistics analysis of distribution of patients with hearing loss in $2-8 \mathrm{kHz}$ and without hearing loss related to hearing complaint.

\begin{tabular}{cccc}
\hline $\begin{array}{c}\text { with } \\
\text { compliant } \\
n(\%)\end{array}$ & $\begin{array}{c}\text { without } \\
\text { compliant } \\
n(\%)\end{array}$ & total & P(\%) \\
\hline
\end{tabular}

With loss

\begin{tabular}{lcccc} 
between & & & & \\
$2 \mathrm{ke} 8 \mathrm{kHz}$ & $14(10 \%)$ & $1(1 \%)$ & $15(11 \%)$ & $<0.000$ I \\
Withoutloss & $10(7 \%)$ & $115(82 \%)$ & $125(89 \%)$ & \\
\hline Total & $24(17 \%)$ & $116(83 \%)$ & $141(100 \%)$ & \\
\hline
\end{tabular}

Table 7. Statistics analysis of distribution of patients with hearing loss only in $\leq \mathrm{I}-8 \mathrm{kHz}$ and without hearing loss related to the hearing complaint.

\begin{tabular}{|c|c|c|c|c|}
\hline & $\begin{array}{c}\text { with } \\
\text { compliant } \\
\mathrm{n}(\%)\end{array}$ & $\begin{array}{l}\text { without } \\
\text { compliant } \\
\mathrm{n}(\%)\end{array}$ & $\begin{array}{l}\text { total } \\
\mathrm{n}(\%)\end{array}$ & $P$ \\
\hline $\begin{array}{l}\text { With loss } \\
\leq \mathrm{kH} \mathrm{k}-8 \mathrm{kH} \\
\text { Without loss }\end{array}$ & $\begin{array}{l}z 6(5 \%) \\
10(8 \%)\end{array}$ & $\begin{array}{c}0(0 \%) \\
116(88 \%)\end{array}$ & $\begin{array}{c}6(5 \%) \\
125(89 \%)\end{array}$ & $<0.000$ \\
\hline Total & $16(12 \%)$ & II 5 (83\%) & 131 (100\%) & \\
\hline
\end{tabular}

(16) found complaint in his study 30 musicians. The authors did not specified the hearing involvement of individuals with complaint, however highlighted the most frequent complaint in relation to buzz and the difficulty to comprehend in noisy environment.

In studies involving hearing complaint in the Portuguese speaking population, CALVITI et al (17), TeIXeIRA et al. (15) and SAmelu et al.(18) studied the relation of hearing loss and hearing complaint, however did not studied the relation of hearing loss with frequencies affected, but with the average of the frequencies and the level of hearing loss. The risk to indentify by average, whether encompassing 500 to $2 \mathrm{kHz}$ or 500 to $4 \mathrm{kHz}$, or including $6 \mathrm{kHz}$, is that in average we lose some individual values which can make a difference. CALviti et al. (17) studied 71 elders, evaluating the relation between the perception of the handicap and the audiometric averages. It was found presence of perception of handicap in 24 elders $(58,5 \%)$ with hearing loss using tone average of 500 to $2 \mathrm{kHz}$, and it was not found significative variation when included in the average the frequencies of $4 \mathrm{k}$ and $6 \mathrm{kHz}$. Teixeira et al. (15) found only 10 elders (20\%) with hearing loss and with complaint, while 23 patients (46\%) with loss did not presented complaint. This relation can be justified by the fact of hearing loss in elders, although bilateral and symmetrical, it is of insidious onset, allowing the adaptation in your daily routine of lower hearing demand. In our sample population is younger, with installation during childhood, with hearing demand greater than the elders.

Currently, there are many ways to classify the hearing losses, however all of them are based on average of tone thresholds of 500, 1000 and $2000 \mathrm{~Hz}$. This was not effective in the cancer population (10), due to the hearing losses by ototoxicity began in the higher frequency and the present study showed when it reached $4000 \mathrm{~Hz}$, it began to appear at hearing complaints. In this way, only taking into account the losses in the frequencies of 500, 1000 e 2000, is not enough to identify the presence of loss with impact in the communication or hearing complaint.

SAmeli et al. (18) studied the possibility of using the raising complaints as method of triage in elderly. They studied 185 elderly and answered the questionnaire raising complaints, which was supplemented by audiological evaluation in 91 of them. Among the elders who performed that audiological evaluation, they found 40 individual (44\%) without hearing complaint and with hearing complaint from mild to profound. Calviti et al. (17) found 17 elderly (24\%) among of 71 studied with hearing loss and without complaint. In our study, among the patients with loss, we found 41 (21\%) who did not presented complaint. From these, 34 patients (33\%) had loss only in $8 \mathrm{kHz}$ or in $6 \mathrm{k}$ and $8 \mathrm{kHz}$ (Table 2). This fact has already been observed by our group, in the work of Liberman et al. (19) in which we highlighted minor losses can be asymptomatic. In other words, isolated hearing loss in high frequency can be asymptomatic, reinforcing the importance of audiological investigation in all other oncologic patients, regardless of hearing complaints. 
In our study, we observe that the presence of hearing complaints increased considerably when the loss advanced to the frequencies which interfered directly in recognizing the acute phonemes, such as the fricatives ( 8 , 20). It was possible to indentify the frequency of $4000 \mathrm{~Hz}$, as statistically significant $(p<0.0001)$ for the onset of hearing complaint, which means that, from this frequency, the impact and the hearing difficulty are imposed. It is noteworthy that although it did not had practically had complaints in the young adult patients with hearing loss in $6 \mathrm{k}$ and $8 \mathrm{kHz}$, theses losses may have important consequences in the pediatric population in development of speech and language.

This study is of utmost importance in oncologic patient when the frequency of $4 \mathrm{kHz}$ is affected we can signal to the oncologist that the hearing loss at the moment will have an important impact in the life of that patient and the oncologist could use the information for the definition of conduct, mainly in the pediatric population.

\section{CONCLUSION}

The greater the number of the frequencies affected the greater id the occurrence of hearing complaint, especially when the frequencies of speech are not involved, and the involvement of $4 \mathrm{kHz}$ already determines the appearance of complaints.

\section{BibLIOGRAPHIC REFERENCES}

1. Santin JC, Deheinzelin D, Junior SP et al. Late echocardiography assessment of systolic and diastolic function of the left ventricle in pediatric cancer survivors after anthracycline therapy. J Pediatr Hematol Oncol. 2007, 29:761-5.

2. Rigon H, Lopes LF, do Rosario Latorre M, de Camargo B. The Gepetto program for surveillance of long-term survivors of childhood cancer: preliminary report from a single institution in Brazil. Med Pediatr Oncol. 2003, 40:405-6.

3. Pinto VMC. Efeitos tardios dentais e maxilofaciais em pacientes tratados de leucemias agudas na infância. São Paulo; 2005. [Dissertaçãode Mestrado-Fundação Antônio Prudente].

4. Garcia VP, Martinez AF, Agusti EB, Mencía LA, Asenjo VP. Drug-induced ototoxicy: current Status. Acta Otolaryngol. 2001, 121:569-72.

5. Simon T, Hero B, Dupuis W, Selle B, Berthold F. The incidence of hearing impairment after successful treatment of neuroblastoma. Klin Padiatr. 2002, 214:149-52.
6. Skinner R. Best practice in assessing ototoxicity in children with cancer. Eur J Cancer. 2004, 40:2352-4.

7. Biro K, Noszek L, Prekopp P, Nagyiványi K, Géczi L, Gaudi I, Bodrogi I. Characteristics and risk factors of cisplatininduced ototoxicity in testicular cancer patients detected by distortion product otoacoustic emission. Oncology. 2006, 70(3):177-84.

8. Schochat E. Percepção da fala em perdas auditivas neurossensoriais. In: Lichtig I, Carvallo RMM, editores. Audição: abordagens atuais. São Paulo: Pró-Fono. 1997, p.223-35.

9. SchultzC, Goffi-GomezMV, Pecora Liberman PH, Pellizzon AC, Carvalho AL. Hearing loss and complaint in patients with head and neck cancer treated with radiotherapy. Arch Otolaryngol Head Neck Surg. 2010, 136(11):1065-9.

10. Schultz C, Goffi-Gomez MV, Liberman PH, Carvalho AL. Report on hearing loss in oncology. BrazJ Otorhinolaryngol. 2009, 75(5):634-41.

11. Arora R, Thakur JS, Azad RK, Mohindroo NK, Sharma DR, Seam RK. Cisplatin-based chemotherapy: Add highfrequency audiometry in the regimen. Indian J Cancer. 2009, 46(4):311-7.

12. Vermorken JB, Remenar E, van Herpen C, Gorlia T, Mesia R, Degardin M, et al. Study Group. Cisplatin, fluorouracil, and docetaxel in unresectable head and neck cancer. N Engl J Med. 2007, 357(17):1695-704.

13. Fernandes LC, Santos TMM. Zumbido e audição normal: estudo da supressão das emissões otoacústicas transientes. Braz J Otorhinolaryngol. 2009, 75(3):414-419.

14. Urnau D, Silva PAB, Seligman L. Influência do zumbido no índice percentual de reconhecimento de fala em pacientes normo-ouvintes. Arq Int Otorrinolaringol. 2010, 14(4):450-455.

15. Teixeira AR, Freitas CLR, Millão LF, Gonçalves AK, Junior BB, Santos AMPV, et al. Relação entre a Queixa e a Presença de Perda Auditiva entre Idosos. Arq Int Otorrinolaringol. 2009, 13(1):78-82

16. Amorim RB, Lopes AC, Santos KTP, Melo ADP, Lauris JRP. Alterações auditivas da exposição ocupacional em músicos. Arq Int Otorrinolaringol. 2008, 12(3):377-383.

17. Calviti KCFK, Pereira LD. Sensibilidade, especificidade e valores preditivos da queixa auditiva comparados com diferentes médias audiométricas. Braz J Otorhinolaryngol. 2009, 75(6):794-800. 
18. Samelli AG, Negretti CA, Ueda KS, Moreira RR, Schochat E. Comparação entre avaliação audiológica e screening: um estudo sobre presbiacusia. Braz J Otorhinolaryngol. 2011,77(1):70-76.

19. Liberman PH, Schultz C, Goffi-Gomez MV, Carvalho AL, Pellizzon AC, Testa JR et al. Auditory effects after organ preservation protocol for laryngeal/hypopharyngeal carcinomas. Arch Otolaryngol Head Neck Surg. 2004, 130(11):1265-8
20. Liberman PHP, Schultz C, Goffi-Gomez MVS, Antoneli CGB, Chojniak MM, Novaes PE. Evaluation of ototoxicity in children treated for retinoblastoma: preliminary results of a systematic audiological evaluation. Clinical Translational Oncology. 2011, 5:348-352. 